\title{
Analysis and Consideration of Construction Project Management Course
}

\author{
Yunxia Jiang ${ }^{1, a}$ \\ 1Shanghai Sanda Institute, Shanghai, China 201209 \\ aapril2002@126.com
}

Keywords: project, management, course, construction.

Abstract. Improving the teaching effect of construction project management course and ensuring students to master more project management knowledge in limited time is an important thing in the teaching reform of engineering management specialty.In this paper, the characteristics of construction project management course and some problems in teaching are analyzed. And some suggestions are summarized from the problem analysis in this paper. It is hoped that it can give the relevant departments and people some help.

\section{Introduction}

Construction project management course is a compulsory course for engineering management specialty. It is an applied and comprehensive course which integrates theory and knowledge of management science, engineering technology, engineering economics, construction laws and regulations and so on. It aims to cultivate students' engineering management ability and plays an important role in the training of wide-bore, large-scale civil engineering projects and comprehensive talents.

Generally speaking, the nature of this course determines that it has more conceptual knowledge and less quantitative calculation knowledge. Students are not very interested in conceptual things. If we only talk about concepts emptily, we will not be able to stimulate students' enthusiasm for learning, and we can't well interpret the project management course.

In order to adapt to the current trend of talent demand and in order to improve the quality of large civil personnel training, it is imperative to explore the teaching reform of project management. Therefore, it is necessary to reform and innovate the teaching of project management course, especially for the application-oriented undergraduate students to find a suitable teaching method.

\section{Characteristics}

The project management course has the characteristics of comprehensiveness and practicality, and the course is intersecting with other courses[1].

Strong Practice For undergraduates who lack industry experience, the course not only need teach them the core concepts, processes and methods of project management, but also needs to introduce them into the industry background of Engineering projects. In this course, students can experience the professional sense of project managers. In this course, students can understand the role of specific projects and try to use the knowledge of project management in the simulation of these roles. Therefore, this course need combine theory with practice experience. This course should not only pay attention to the degree of students' mastery of knowledge, but also cultivate the practical ability and thinking mode of project management.

Comprehensiveness and Commitment. In the engineering project management, it is necessary to apply different kinds of knowledge of specialized courses. Therefore, the course need deal with the relationship with other specialized courses, such as engineering economics, engineering contract management, engineering valuation, construction organization and design[2,3]. Although this course can `t replace the above courses, but it can help students to establish a framework outline of using project management knowledge, which can help students to form a comprehensive understanding of the relationship among the specialized courses. Therefore, this course plays an important role in the 
whole teaching system. And this course should not only teach project management knowledge, but also provide an outline of practical knowledge.

\section{Existing Problems of the Course Construction}

From teaching experience, comprehensive document analysis and expert inquiry, the existing problems in the teaching of engineering project management are put forward in the following contents.

Course Content.The content of the course is difficult and repetitive[2]. The link among courses is not good, and teaching contents are partial and disjointed. The knowledge points of the course are fragmented. The interaction and systematization of different courses are inadequate. The contents of the course lack professional ethics education content.

Course Materials.There are many course materials for construction project management course. But in these textbooks, there are few teaching materials.And the content of textbooks is not perfect. In addition, the course materials covers a wide range. And because of the rapid development of subjects, it is difficult to choose textbooks.

Teaching Methods.In the course of teaching, most teachers adopt instilling spoon feeding[3]. The teaching method is single and obsolete.And the assessment method is single. Some teachers copy the books from the beginning to the end and ignore the teaching effect in the classroom. Multimedia teaching sometimes only moves the content which should have been written on the blackboard onto the screen. Teaching methods have changed, but there is no essential change in teaching contents and teaching effects.

Practice Teaching Activities.Practice teaching links are weak, independent and lack of overall design. Some practice teaching activities only arrange one or two on-site visits without any aim. In some practical teaching activities, teachers have no specific teaching requirements and objectives so that students can`t learn practical skills.

Information Technology. In the course of teaching, information technology platform can $t$ be fully applied.And the necessary application skills of project management system software are missing.

Teachers' Quality.Some teachers are not very professional[3]. And they do not attach importance to extracurricular supplementary teaching. In addition, the quality of teachers sometimes can`t meet the requirements of practical teaching.

\section{Comprehensive Suggestion}

Based on the existing problems in the actual teaching, we should actively put into the reform of the course teaching. And we should start from the foundation and start from the needs of teaching and students. Only in this way, we can meet the needs of the society for engineering management application-oriented talents and deepen the teaching reform step by step.

From teaching experience, comprehensive document analysis and expert inquiry, the following suggestions are summarized in this paper.And I hope that these suggestions can give teachers some references.

Course Content. First, pay attention to the introduction of background knowledge. Second,combine the content of national qualification examination and the content of PMBOK knowledge system.And design the teaching content under the principle of integrating theory with practice.Third,strengthen the course design link. And comb the course structure. Optimize the teaching content settings and effectively handle the cross-cutting content with other courses.Fourth,closely follow the frontiers of disciplines and pay attention to the latest achievements of project management at home and abroad. Then select teaching contents carefully.Fifth,we should design the teaching content systematically and concretely[4]. 
Selection and Construction of Course Materials.We should choose the right course materials according to our own conditions. If conditions permit, we can compile our own course materials for our students.

Teaching Methods.First,optimize the learning platform. Build curriculum exercises database and diversified learning resources.Second,course construction keeps pace with the times. Reconstruct and innovate teaching methods and teaching processes.Third,take the training instead of the exam, take the card instead of the exam, and take the contest instead of the exam.Fourth,adopt heuristic and case teaching method to cultivate students' innovative thought[4].Fifth,adopt discussion teaching mode to fully arouse students' learning enthusiasm.Sixth,reform examination methods and ways to establish a reasonable assessment method.Seventh,adopt diversified teaching methods. The teaching method can choose the mode of "theory teaching + case analysis method + questioning + classroom practice + multimedia teaching + curriculum design + engineering practice + on-site visit + information technology"[5,6,7,8].

Practice Teaching and Informationization.First,go out and import. Build laboratories. Carry out comprehensive training courses, such as project management sand table simulation teaching[5,6]. Build a curriculum system which can strengthen practical teaching.Second,attach importance to the industry in teaching content. Increase the practice link. Take students to study at the construction site, and guide students to use summer vacation to carry out on-site practice. Through on-site visits, students can deepen their understanding of quality control, safety control, cost control, on-site management.And on-site visits maybe stimulate students to explore independent learning mechanism. Third,strengthen the combination of theory and practice in teaching. Fourth, practical teaching content can be examined by questioning and discussion defense[7]. Such different forms of examination can not only ensure the quality of students' practice, but also make the practice results real and effective. Fifth,keep pace with the times and add information management content. Build an information management environment and build a suitable project management system application software teaching platform for this course.

Teaching Staff.First,teachers should change their concepts and improve their understanding.Second,strengthen the training of teachers' practical ability and train double qualified teachers.Third,improve the quality of teachers and the level of professional teachers' informationization.Build the corresponding teaching staff. Fourth, professional teachers must strengthen our own knowledge reserves and constantly convey the latest subject development information and frontier subject knowledge to students. Professional teachers should carry out more academic discussions and exchanges so that they can absorb some advanced teaching methods and experience. Only in this way, we can cultivate some applied talents who can adapt the society well.

\section{Conclusions}

In the current engineering management industry, the comprehensive practical ability and professional adaptability of engineering project management professionals have been put forward higher requirements. The construction project management course is an important course to cultivate students' innovative consciousness and practical ability. In this paper, the characteristics of the course of construction project management and some problems in teaching are analyzed. Some suggestions are put forward to improve the construction project management course from the aspects of teaching content, textbook selection, teaching methods and means, practical teaching and informationization, teaching staff and so on. The aim is to promote the teaching of construction project management course to suit the current trend of talent demand. And the aim is to improve the quality of personnel training for large civil engineering majors. 


\section{References}

[1]Xinping Dong,Yingcun Cai,Reform on Teaching Contents of Engineering Project Management Course. Journal of Architectural Education in Institutions of Higher Learning.Vol.20(2011),p,57-60.

[2]Qunwei Zhang,Shuwei Sun. Teaching Reform and Innovation of Engineering Project Management Course. Journal of Hubei Correspondence University. Vol.27(2014),p,117-118.

[3] Haiyan Sun."Engineering Project Management" The Curriculum Educational Reform I See. Science \& Technology Information. Vol.5(2010),p,167.

[4]Merseth K K:Case in Educational Administration(Addison Wesley Publisher, New York 1997).

[5]Peng Mao. Application of sand table in project management teaching. Journal of Architectural Education in Institutions of Higher Learning.Vol.21(2013),p,89-93.

[6]Jianwen Huang, Qin Huang, Ting Zhang, Wenjuan Ma. Process Design of Sand Table Simulation in Engineering Project Management Based on "Sandwich" Mode.Architectural Education in Institutions of Higher Learning.Vol.23(2014),p,136-140.

[7]Hongxia Liu. The Revelation of Dole`s "4R" Curriculum to Project Management Teaching. Shang Xi Architecture. Vol.40(2014),p,246-247.

[8]Guangxiu Fang. Case Teaching Research on Project Management Courses. Journal of Yanbian University(Natural Science). Vol.39(2013),p,316-318. 